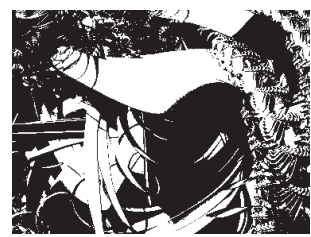

\title{
"AMERIKANIZACIJA" KAMPANJE U HRVATSKOM DNEVNOM TISKU: IZBORI 2007.
}

Ivan BALABANIĆ, Marko MUSTAPIĆ, Stanko RIHTAR

Institut društvenih znanosti Ivo Pilar, Zagreb

UDK: 32.019.5(497.5)"2007":324

$324(497.5) " 2007^{\prime \prime}: 070$

Izvorni znanstveni rad

Primlieno: 2. 9. 2009.

U opsežnoj literaturi koja se bavi političkom komunikacijom navodi se da su njezina glavna obilježja otuđenost stranaka od građana, scijentifikaciija, autonomna struktura komunikacije te transformacija građana ili biračkoga tijela u gledateljstvo. Kad je riječ o oglašavanju kao dijelu političke komunikacije, na operativnoj razini, i to posebno u okviru predizbornih kampanja, spomenuta se obilježja očituju kao personalizacija isticanjem vođa (ili ostalih članova stranaka), svođenje složenijih programskih smjernica na poruke u obliku slogana, isticanje simbola moći i statusa te izravno napadanje političkih konkurenata (negativna kampanja). S obzirom na podrijetlo, opisani se stil oglašavanja često naziva "amerikaniziranim". U radu je provjereno mogu li se, na primjeru parlamentarnih izbora 2007., u predizbornom oglašavanju u našem tisku prepoznati glavni elementi opisanoga načina prezentacije. Analiza sadržaja svih političkih oglasa objavljenih za trajanja službene kampanje u šest glavnih novinskih izdanja pokazala je da su glavni elementi "amerikanizacije" najprisutniij u oglasima HDZ-a, koji je i najviše uložio u tu svrhu. Zahvaljujući tome što su istom načinu oglašavanja, u većoj ili manjoj mjeri, bile sklone i ostale stranke, zaključeno je da je u našem tisku u dobroj mjeri usvojen "amerikanizirani" način predizborne promocije.

Ključne riječi: predizborna kampanja, političko oglašavanje, dnevni tisak, "amerikanizacija" 
Masovni su mediji nezaobilazan kanal komunikacije u suvremenom društvu. Hardt i Negri (2003.) smatraju ih ključnim čimbenikom oblikovanja "nove masovne društvenosti", a Street (2003.a) naglašava da oni, budući da su u velikoj mjeri marketinški usmjereni, publiku više smatraju potrošačima nego građanima. U takvu okruženju u političkoj komunikaciji (što posebice vrijedi za predizborne kampanje) dominira oglašavanje, čime se ona udaljuje od normativnog ideala liberalno-demokratskoga procesa u kojem građani uče i racionalno izabiru na temelju političkih programa (Joslyn, 1986.). Castellsova (2004.) je, pak, teza da suvremeni mediji nisu puko sredstvo manipulacije ili indoktrinacije, nego prostor $u$ kojemu se politika događa, pa se ona stoga i organizacijski, proceduralno i stilom rukovođenja nužno prilagođuje logici medijskih sustava.

McNair (2003.) suvremenu politiku naziva predstavom u okviru koje političku komunikaciju vidi kao umijeće uvjeravanja građana $\mathrm{u}$ okviru demokratskih procesa. Ta komunikacija nije samo uvjeravanje snagom argumenata, a ne može se promatrati ni izvan kulturnoga konteksta u kojem se odvija. Street (2003.a, 175) ističe da ona, između ostalog, znači i "osvajanje popularne mašte, davanje simboličke važnosti djelima i idejama". Simbolički, kampanje legitimiraju demokratsku vlast i političke vođe, ujedinjujući glasače i kandidate "u izlogu građanskog pijeteta i rituala nacionalne obnove" (Mancini i Swanson, 1996.).

Tehnike političke komunikacije McNair (2003.) primarno dijeli na oglašivanje i odnose $s$ javnošću. $S$ obzirom na tematsku usmjerenost ovog rada, u daljem tekstu bit će riječi samo o oglašavanju.

Holtz-Bacha i Kaid (1995.) ističu da bi političko oglašavanje trebalo promatrati kao bilo koje kontrolirano komuniciranje porukama kroz bilo koji komunikacijski kanal dizajniran za promicanje političkih interesa pojedinaca, stranaka, grupa, vlada ili organizacija. Isti autori napominju da se moć oglašavanja očituje na dvije razine: osim što politički oglas širi informacije o programu kandidata ili stranke, on nastoji i uvjeriti.

U vrijeme predizbornih kampanja politički akteri odašilju poruke biračkom tijelu prema zakonom određenim pravilima, ${ }^{2}$ najčešće slijedeći načela učinkovita marketinga. "Marketing se u gospodarstvu provodi radi poticanja razmjene između ponuditelja i kupca, gdje prvi dobiva novac, a drugi robu ili uslugu. Marketing je u politici usmjeren na razmjenu političara i građana, gdje političari nude vizije i vodstvo, a građani glasove" (Newman i Perlof, 2004., 19).

Teorijska shvaćanja političkog oglašavanja grubo se mogu podijeliti na dva osnovna pristupa: onaj koji ga poisto- 
DRUŠ. ISTRAŽ. ZAGREB GOD. 20 (2011), BR. 2 (112)

STR. $359-378$

BALABANIĆ, I., MUSTAPIĆ, M., RIHTAR, S.:

"AMERIKANIZACIJA". vjećuje s komercijalnim i onaj koji drži da je političko oglašavanje ipak posebno $\mathrm{u}$ odnosu na komercijalno.

U okviru prvoga pristupa uobičajeno je mišljenje da se oglašavanjem stranke ili kandidati prodaju kao bilo koji drugi proizvod, pa se i traži odgovor na pitanje kako se to zapravo odvija ili kako bi se moglo unaprijediti (Schiller, 1984.; Qualter, 1991.; Biocca, 1991.; Greenway i sur., 1992.; Corner, 1995.).

U okviru drugoga pristupa teoretičari političko oglašavanje po svojoj naravi razlikuju od komercijalnog (McNair, 2003.; Scammell i Langer, 2006.). Velika uloga novca na tom području smanjuje jednakost prilika i pristup političkom procesu, a za razliku od drugih roba, politikom se ne nastoji pružiti neposredno i neodgođeno zadovoljstvo publici.

Neovisno o iznesenim teorijskim pristupima, vođenje kampanja i izborni marketing danas su prilagođeni potrošačkom društvu i usmjereni su na estradizaciju politike, ponajviše u obliku spektakla, u čemu se najdalje otišlo u SAD-u.

Povijesni put koji je u zadnjem desetljeću prijeđen do takva stila političkog oglašavanja Blumler i Kvanagh (1999.) dijele u tri glavne faze. U prvoj fazi, koja je započela nakon Drugog svjetskog rata, ono je bilo usmjereno na stranku (kad je riječ o pojedinim porukama ili isticanju programskih razlika) i u znatnoj je mjeri uključivala izravnu komunikaciji s biračima. Kao kanali poslužili su uglavnom stranački tisak, tiskani oglasi i radio.

Druga faza započinje 1960-ih godina, kad televizija postaje dominantan i najutjecajniji medij. Usmjerenost se sa stranaka premješta na kandidate, koji su se pak morali prilagoditi novoj medijskoj logici koja naglašava vizualni dojam i osobnost. Započinje angažiranje konzultanata i upotreba "spinova", pažljivo se biraju teme i naglasci kampanje i planira slika kandidata koja se plasira televizijskim reklamama.

Treća faza, koja je započela potkraj 20. stoljeća, još traje i obilježava je sve veća profesionalizacija kampanja. U sve se većoj mjeri angažiraju savjetnici za kampanju i oglašavanje i redovito se provode istraživanja javnoga mišljenja, osobina i preferencija birača. Na temelju spoznaja do kojih se tako dolazi oblikuju se i emitiraju poruke, sadržaj kojih je namijenjen ciljanim skupinama publike. Osim fragmentacije biračkoga tijela, za potrebe kampanje selektivno se rabe i komunikacijski kanali (i upotrebljavaju novi, poput interneta i elektroničke pošte). Važnost sadržaja političkih poruka znatno više nego u prethodnim razdobljima uzmiče pred načinom njihova prezentiranja (Street, 2003.a ili b; McNair 2003.; Van Zoonen, 2003.), na što, između ostalog, upućuje i sve veći angažman 'spin doktora' i konstruiranje pseudodogađaja. Newman (1999.) ističe da je tradicionalna stranačka privrženost i identifikacija sa strankama s vremenom erodirala, uz porast broja neodluč- 
nih i nepredvidivih glasača i izbornih apstinenata. Jasno je da u takvim okolnostima kampanja sve više dobiva na važnosti (Holtz-Bacha, 2002.).

\section{"Amerikanizacija" izborne kampanje}

Opisana transformacija suvremene politike u trećoj fazi, pogotovo kad se promatra kroz prizmu medijskih aktivnosti kojima se ona prodaje u tzv. "upakiranom" ili "dizajniranom" obliku, često se označuje i pojmom "amerikanizacija" (Franklin, 1994.; Scammell, 1995.).

Swanson i Mancini (1996.) navode da su glavni elementi suvremene "amerikanizirane" kampanje, uz prethodno spomenuta opća obilježja (koja uključuju otuđenost stranaka od građana, scijentifikaciju, autonomnu strukturu komunikacije te transformaciju građana ili biračkoga tijela u gledateljstvo), na konkretnijoj, provedbenoj razini još i personalizacija, svođenje poruka na slogane, isticanje simbola moći i statusa te izravno napadanje političkih konkurenata (negativna kampanja).

U skladu s naznakom o personalizaciji, Corner i Pels (2003.) misle kako u "postideologijskom i poststranačkom vremenu" publiku više zanimaju stil, osobnost i prepoznatljivost političara nego sadržaj njihovih političkih poruka. "Imidž je umjetni proizvod čija je inscenacija dobro proračunata, a njome se 'prirodna' osoba prikazuje kao personifikacija svojstava koja se $\mathrm{u}$ mitologiji ili etici njezine zajednice smatraju posebno vrijednim" (Mayer, 2003., 63).

U odnosu na takav sadržaj i način političke prezentacije, sadržajno složeniji informacijski paketi s političkim programom teže će zainteresirati birače. Umjesto toga, nude se koncentrirane, kratke poruke u obliku slogana. Slogan je koristan kao ugodna fraza bez precizna značenja ili "sredstvo lako razumljive komunikacije koje budi emocije birača i olakšava prodor neke političke zamisli ili poruke do milijuna ljudi" (Kasapović, 2003., 158). Tekstovi i slogani vrlo su često neodređeni, to su vješto dotjerane generalizacije kojima je cilj što većem broju ljudi predstaviti, učiniti shvatljivim i prihvatljivim ključne političke sadržaje (Scammell, 1999.; Holtz-Bacha, 2003.). Slavujević (2005.) dijeli ih na tri vrste: slogan-tema, imidž-slogan i slogan-poziv. Slogan-tema izdvaja bit nekoga političkog programa ili stava, opći ili konkretan politički ili socijalni cilj koji se želi postići. Njime se često iskazuje određeno ideološko opredjeljenje ili društveni problem i način njegova rješavanja. Imidž-slogan usredotočuje se, prije svega, na opće ili pojedinačne kvalitete stranke ili kandidata. Slogan-poziv potiče birače na akciju, odnosno motivira ih da što veći broj pristaša određene stranke ili kandidata potaknu da se odazovu izborima. Najčešće se primjenjuju u samoj završnici kampa- 
DRUŠ. ISTRAŽ. ZAGREB GOD. 20 (2011), BR. 2 (112)

STR. $359-378$

BALABANIĆ, I., MUSTAPIĆ, M., RIHTAR, S.:

"AMERIKANIZACIJA". nje, kad su birači već dobro upoznati s kandidatima i njihovim izbornim obećanjima.

Iako su personalizacija i komunikacija u obliku slogana na raspolaganju svima koji sudjeluju u političkoj utrci, upotreba simbola moći i statusa (iako su načelno, i ovisno o okolnostima, na raspolaganju i drugima), posebno ide na ruku onoj stranci koja obnaša vlast u predizbornom razdoblju. McNair (2003., 102-103) navodi primjere iz SAD-a: "Kandidat na vlasti, poput Nixona 1972. ili Regana 1984., neminovno stječe zalihu iskustva i vjerodostojnosti koja se može predstaviti u oglasima korištenjem arhivskih snimki konferencija za novinare, putovanja po inozemstvu, sastanaka s međunarodnim vođama itd. Ti vizualni elementi, s odgovarajućom verbalnom pratnjom, postaju snažne oznake autoriteta nasuprot izazivaču čije je administrativno iskustvo možda ograničeno na upravljanje nekom malom saveznom državom."

Dinamiku opisane, "amerikanizirane" kampanje Diamond i Bates (1992.) razlažu na sljedeće faze: najprije se, na temelju zaodijevanja vrijednostima koje odgovaraju težnjama biračkoga tijela, i to onako kako su ih utvrdila istraživanja, uspostavlja osnovni identitet kandidata kao početni okvir za narav informacija koje će se plasirati; potom se artikuliraju i plasiraju kandidatove politike, i to uopćeno, uz minimum detalja, ali s emocionalnim nabojem; na kraju se političke konkurente napada negativnim oglasima.

Proces "amerikanizacije" kampanja u drugim zemljama, odnosno preuzimanje američkih obrazaca ponašanja političkih aktera i medija, počeo se širiti 1980-ih godina (nakon Amerike, najprije $\mathrm{u}$ Zapadnoj Europi i Australiji, a potom i drugdje), a Swanson i Mancini (1996.) navode da to ne bi bilo moguće bez prethodne modernizacije, odnosno odgovarajućih socijalnih i tehnoloških preduvjeta. Promjena tehnoloških preduvjeta podrazumijeva i promjene u masovnim medijima i načinima komunikacije općenito, pa tako danas komunikacijski kanali omogućuju pošiljateljima ne samo obraćanje javnosti u cjelini nego i građanima pojedinačno. Oglašavati se može reklamnim posterima i displejima, letcima i brošurama, poštom, elektroničkom poštom, dnevnim i periodičnim tiskom, televizijom, radiom i internetom (Kaid, 2004.; Trent i Friedenberg, 2007.).

\section{Političko oglašavanje i dnevni tisak}

U odnosu na ostale suvremene medije, tisak ima najdužu tradiciju. Političko oglašavanje u tiskanom obliku počelo se razvijati na Zapadu od Francuske revolucije, kao posljedica pojave građanskog društva i, zahvaljujući tome, novih političkih sloboda, ali i tehnoloških dostignuća (Crowley, 1998.). Tiskani materijali bili su i glavni medij političkog oglašavanja prije pr- 
DRUŠ. ISTRAŽ. ZAGREB GOD. 20 (2011) BR. 2 (112),

STR. $359-378$

BALABANIĆ, I., MUSTAPIĆ, M., RIHTAR, S.:

"AMERIKANIZACIJA".
Doulkeri i Kotzaivazoglou (2007.) ističu da se, po namjeri i stilu, političko oglašavanje u tisku u općim crtama bitno ne razlikuje od onoga u ostalim masovnim medijima. Primarna je izgradnja opće naklonosti (sviđanja) i povjerenja u političke aktere naglašavanjem autoriteta, izgleda i šarma, dok je iznošenje političkih pogleda i programa, premda se ne zanemaruje, sekundarno. Osim toga, komercijalnim oglašavanjem u tisku (kojim se publici obraća izravno, bez uredničkih intervencija) i u ostalim masovnim medijima može se u znatnoj mjeri zaobići uređivačka politika, koja inače utječe na sadržaj, vrijednosnu orijentaciju i formu političke komunikacije. ${ }^{3}$

Iako se danas, zbog dosega i utjecaja, televizijska prezentacija smatra važnijom i u nju se više ulaže nego u onu u tisku, ipak tisak nije sasvim izgubio na poželjnosti, jer je kao oglasni medij zadržao neke posebnosti. Za ilustraciju, mogu se navesti neke od njih.

Prvo, bez obzira na razmjerno skromniji doseg, čitanje novina još je uvijek "svakodnevni ritual" dijela građana koji se, kako pokazuju istraživanja, statusno i obrazovno izdižu iznad populacijskoga prosjeka, a svojom brojnošću čine nezanemariv i, za ciljano predstavljanje, zanimljiv segment ukupnoga biračkog tijela (Lamza Posavec i Rihtar, 2003.).

Drugo, novine (uz internet) $u$ većoj mjeri od televizije dopuštaju upotrebu prema vlastitu ukusu i potrebama, a prihvat informacija, za razliku od vremenski ograničenih emisija na radiju ili televiziji, u većoj je mjeri određen voljom čitatelja. Dosljedno tome, svakom oglasu publika može biti izložena višekratno (svaki put kad se prelista isti primjerak novina), dok je emitiranom spotu ili reklami izložena jednokratno.

Treće, ako je nužno "u hodu" mijenjati strategiju ili plan kampanje, što znači sadržaj, formu i/ili brojnost oglasa, tiskani su mediji u prednosti (posebno dnevni tisak) ne samo zbog toga što je to u njima tehnički brže i jednostavnije izvesti nego i zbog toga što je znatno jeftinije. Ako je pak oglasni prostor zakupljen unaprijed, on se također može iskoristiti za brze promjene tema i sadržaja oglasnih poruka (Trent i Friedenberg, 2007.).

Četvrto, oglašavanje u predizbornom razdoblju različito je zakonski regulirano od zemlje do zemlje (Holtz-Bacha i Kaid, 1995.). Iako je u većini njih predviđeno besplatno vrijeme za predstavljanje stranaka i kandidata na pojedinim televizijskim kanalima, u nekima je, poput Švicarske, na televiziji i radiju zabranjeno. U takvim redukcijama ukupnoga oglasnog prostora tisak, sam po sebi, dobiva na važnosti.

\section{CILJEVI ISTRAŽIVANJA}

\footnotetext{
Opisane posebnosti čine tisak i dalje, bez obzira na manji doseg, dovoljno privlačnim medijem političkoga predstavljanja. Vodeći računa o tome da se novinsko političko oglašavanje,
} 

GOD. 20 (2011), BR. $2(112)$

STR. $359-378$

BALABANIĆ, I., MUSTAPIĆ M., RIHTAR, S.

"AMERIKANIZACIJA".
DRUŠ. ISTRAŽ. ZAGREB

po namjeri i stilu, u općim crtama bitno ne razlikuje od onoga $\mathrm{u}$ ostalim masovnim medijima (Doulkeri i Kotzaivazoglou, 2007.) te da istraživanja koja bi se bavila tom problematikom u domaćem tisku nisu provedena, ${ }^{4}$ glavni je cilj ovog rada utvrditi slijedi li i novinsko oglašavanje hrvatskih političkih stranaka tijekom kampanje uvodno opisane trendove ili, preciznije, odgovoriti na pitanje jesu li i u kojoj mjeri i u našem tisku prisutni elementi "amerikaniziranog" načina predizborne promocije. U skladu s time pokušat će se utvrditi:

1) u kolikoj je mjeri oglašavanje personalizirano isticanjem osobe predsjednika ili predsjednice stranke te prikazuju li oglasi javnosti poznate osobe ${ }^{5}$ (primjerice, estradne i sportske zvijezde)

2) temelje li se oglasi političkih stranaka uglavnom na sloganima, naglašava li se pretežno slikovni materijal (i koja su mu glavna obilježja) ili se iznose i konkretne programske odrednice

3) je li i u kojoj mjeri zastupljeno ciljano obraćanje pojedinim segmentima biračkoga tijela

4) je li se stranka na vlasti (HDZ) poslužila aktualnom pozicijom za isticanje simbola moći i statusa (naglašavanje susreta sa stranim državnicima i slično)

5) u kojoj je mjeri zastupljena negativna kampanja (oglasi izravno usmjereni protiv drugih stranaka).

Osim prisutnosti "amerikaniziranog" načina komunikacije u novinskoj kampanji općenito, pokušat će se utvrditi postoje li i kakve su u tom pogledu razlike među vodećim strankama.

\section{METODA}

U Hrvatskoj je 2007. godine izlazilo 12 dnevnih listova. Među njima su, za potrebe ovog rada, izdvojeni najvažniji nacionalni (tri najčitanija, 24 sata, Večernji i Jutarnji list), potom nacionalni list s najdužom tradicijom neprekinutog izlaženja (Vjesnik) te dva najčitanija regionalna lista (Slobodna Dalmacija i Novi list).

Istraživanje je provedeno analizom sadržaja. Kao jedinica analize poslužio je jedan politički oglas, odnosno oglas kojim se predstavljala određena politička stranka ili nezavisna lista. Obuhvaćeni su svi oglasi te vrste koji su tijekom službene kampanje, od 3. studenog do 23. studenog 2007., objavljeni $\mathrm{u}$ navedenim novinskim izdanjima. Za potrebe analize konstruirana je matrica koja je sadržavala 15 klasifikacijskih kategorija: datum objavljivanja oglasa; novine u kojima je objavljen; stranica na kojoj se nalazi; površina; stranka koja se njime oglašava; forma oglasa; što se oglasom naglašava; što na- 
DRUŠ. ISTRAŽ. ZAGREB GOD. 20 (2011)

BR. 2 (112),

STR. 359-378

BALABANIĆ, I., MUSTAPIĆ M., RIHTAR, S.

"AMERIKANIZACIJA". glašava slikovni sadržaj oglasa; što naglašava tekstualni sadržaj oglasa; koja se vrsta slogana rabi; ima li oglas konkretnu temu ili program i, ako ima, koju; koja je svrha oglasa te, na kraju, kakva je njegova vrijednosna orijentacija.

Analizu sadržaja provela su dva autora ovog rada. Radi postizanja jednoznačnosti kriterija, najprije je izrađena radna verzija analitičke matrice te je provedeno nekoliko pokusnih analiza. Podudarnost analitičara ispitana je Cohen Kappa koeficijentom, koji se, ovisno o varijabli istraživanja, kretao od 0,75 do 0,90 (za novinu, stranicu, političku stranku i površinu oglasa podudarnost nije mjerena). Medijan koeficijenta svih varijabli iznosi 0,86 (Cohen Kappa koeficijent viši od 0,80 upućuje na izrazito visoku podudarnost). ${ }^{6}$

\section{REZULTATI}

\section{Intenzitet i dinamika oglašavanja u vrijeme kampanje 2007.}

Opća slika strukture i dinamike političkog oglašavanja $u$ analiziranim novinama prikazana je u Tablici 1 i na Slici 1. Tablica 1 sadrži podatke o ukupnom broju i zastupljenosti oglasa prema pojedinim tiskovinama. Kako je kod nas prisutna zamjetna bipolarizacija političke scene, ${ }^{7}$ ali i zbog bolje preglednosti u njoj su prikazani podaci za dvije dominantne stranke (HDZ i SDP), kao i za koaliciju HSS-HSLS, jer je objavila više oglasa od SDP-a. Podaci za sve ostale oglašivače zbrojeni su.

Političke su stranke $u$ analiziranim novinskim izdanjima objavile ukupno 440 oglasa. Ako se uzme u obzir da je službena kampanja trajala 21 dan, to znači da ih je na dan u prosjeku objavljeno 21, odnosno 3,5 oglasa po tiskovini. Taj bi broj bio znatno manji da samo jedna stranka (HDZ) nije objavila 275 , odnosno $63 \%$ od ukupnoga broja oglasa. SDP, po snazi druga stranka u Hrvatskoj (što znači da, uz HDZ, logistikom, brojem članova i saborskim mandatima odudara od manjih stranaka), u analiziranim je novinama objavio tek 49 oglasa, odnosno prosječno 2,3 na dan. Osim toga, većina SDP-ovih oglasa (39 od ukupno 49) bila je najmanje površine (manje od četvrtine novinske stranice). Za usporedbu, HDZ je objavio 128 oglasa $(47 \%)$ preko cijele stranice. Nadalje, SDP je više od $60 \%$ svojih oglasa objavio u Novom listu, dok se HDZ razmjerno ravnomjerno oglašavao $u$ analiziranim novinskim izdanjima. Koalicija HSS-HSLS objavila je 74 oglasa, njihovim brojem i formatom forsirajući promociju u Slobodnoj Dalmaciji (u tom je listu objavljeno gotovo pola, odnosno $41 \%$ od svih oglasa koalicije, uključujući dvije trećine ukupnog broja oglasa preko cijele stranice). Ostale stranke objavile su 42 oglasa, pri čemu su u nešto više od pola slučajeva (52\%) izabrale 24 sata kao najpovoljniji oglasni medij. 


\begin{tabular}{|c|c|c|c|c|c|c|c|c|}
\hline & & $\begin{array}{r}\text { Večernji } \\
\text { list }\end{array}$ & $\begin{array}{r}\text { Jutarnji } \\
\text { list }\end{array}$ & $\begin{array}{r}\text { Slobodna } \\
\text { Dalmacija }\end{array}$ & 24 sata & Novi list & Vjesnik & Ukupno \\
\hline \multirow[t]{6}{*}{ HDZ } & Cijela stranica & 17,2 & 19,5 & 21,1 & 18,0 & 16,4 & 7,8 & 100,0 \\
\hline & $1 / 2$ stranice & 9,1 & 27,3 & 27,3 & 15,2 & 21,2 & 0,0 & 100,0 \\
\hline & $1 / 4$ stranice & 13,0 & 19,0 & 16,0 & 17,0 & 19,0 & 16,0 & 100,0 \\
\hline & $<1 / 4$ stranice & 0,0 & 0,0 & 0,0 & 7,1 & 92,9 & 0,0 & 100,0 \\
\hline & $\mathrm{N}$ & 38 & 53 & 52 & 46 & 60 & 26 & 275 \\
\hline & $\%$ & 13,8 & 19,3 & 18,9 & 16,7 & 21,8 & 9,5 & 100,0 \\
\hline \multirow[t]{6}{*}{ SDP } & Cijela stranica & 14,3 & 14,3 & 42,9 & 0,0 & 28,6 & 0,0 & 100,0 \\
\hline & $1 / 2$ stranice & 0,0 & 0,0 & 100,0 & 0,0 & 0,0 & 0,0 & 100,0 \\
\hline & 1/4 stranice & 0,0 & 0,0 & 0,0 & 100,0 & 0,0 & 0,0 & 100,0 \\
\hline & $<1 / 4$ stranice & 10,0 & 10,0 & 10,0 & 0,0 & 70,0 & 0,0 & 100,0 \\
\hline & $\mathrm{N}$ & 5 & 5 & 8 & 1 & 30 & 0 & 49 \\
\hline & $\%$ & 10,2 & 10,2 & 16,3 & 2,0 & 61,2 & 0,0 & 100,0 \\
\hline \multirow[t]{6}{*}{ HSS-HSLS } & Cijela stranica & 13,3 & 0 & 66,7 & 13,3 & 6,7 & 0,0 & 100,0 \\
\hline & $1 / 2$ stranice & 0 & 33,3 & 33,3 & 0,0 & 33,3 & 0,0 & 100,0 \\
\hline & $1 / 4$ stranice & 3,3 & 30 & 60,0 & 6,7 & 0,0 & 0,0 & 100,0 \\
\hline & $<1 / 4$ stranice & 38,5 & 30,77 & 3,9 & 3,9 & 23,1 & 0,0 & 100,0 \\
\hline & $\mathrm{N}$ & 13 & 18 & 30 & 5 & 8 & 0 & 74 \\
\hline & $\%$ & 17,6 & 24,3 & 40,5 & 6,8 & 10,8 & 0,0 & 100,0 \\
\hline \multirow[t]{8}{*}{ OSTALI } & Cijela stranica & 0,0 & 0,0 & 12,5 & 37,5 & 50,0 & 0,0 & 100,0 \\
\hline & $1 / 2$ stranice & 40,0 & 10,0 & 40 & 0,0 & 10,0 & 0,0 & 100,0 \\
\hline & $1 / 4$ stranice & 0,0 & 0,0 & 0 & 66,7 & 33,3 & 0,0 & 100,0 \\
\hline & $<1 / 4$ stranice & 5,6 & 0,0 & 11,1 & 83,3 & 0,0 & 0,0 & 100,0 \\
\hline & $\mathrm{N}$ & 5 & 1 & 7 & 22 & 7 & 0 & 42 \\
\hline & $\%$ & 11,9 & 2,38 & 16,7 & 52,4 & 16,67 & 0,0 & 100,0 \\
\hline & N ukupno & 61 & 77 & 97 & 74 & 105 & 26 & 440 \\
\hline & $\%$ ukupno & 13,8 & 17,5 & 22,2 & 16,8 & 23,8 & 5,9 & 100,0 \\
\hline
\end{tabular}

(1) TABLICA 1

Prostorna zastuplienost predizbornih oglasa pojedinih političkih

stranaka prema

analiziranim dnevnim novinama

$\rightarrow$ SLIKA 1

Dinamika novinskog oglašavanja stranaka po tjednima izborne kampanje
Vremensku dinamiku stranačkoga predstavljanja u analiziranom tisku prikazuje Slika 1.

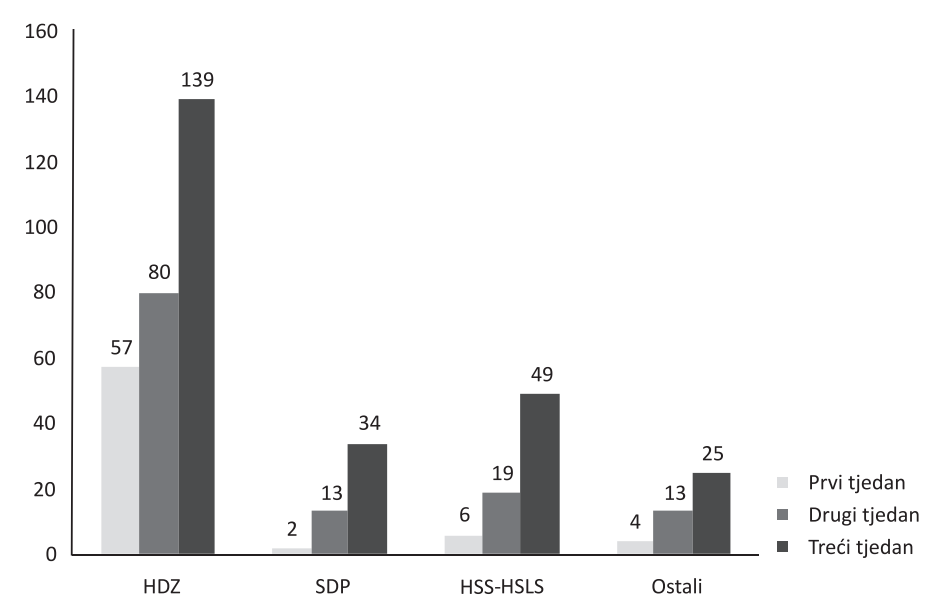


Iz slike se jasno vidi opći porast intenziteta oglašavanja tijekom kampanje, što vrijedi za sve stranke. U slučaju HDZ-a, SDP-a i koalicije HSS-HSLS, zapaža se gotovo eksponencijalan porast broja oglasa po tjednima, dok je intenzitet oglašavanja ostalih stranaka rastao nešto ravnomjernije.

\section{Sadržajne osobine političkih oglasa}

(1) TABLICA 2

Zastupljenost sadržajno različitih predizbornih oglasa prema strankama i veličini oglasnoga prostora

Forma oglasa
Bez obzira na intenzitet oglašavanja, na pitanje prati li ono uvodno opisane trendove može se odgovoriti analizom vrsta ili oblika političkih oglasa. Njihovu zastupljenost prema strankama i pojedinim tiskovinama prikazuje Tablica 2.

HDZ

Fotografije stranačkih osoba sa sloganima

Fotografije stranačkih osoba sa sloganima i tekstom

Fotografije stranačkih osoba s tekstom

Samo fotografije stranačkih osoba

Fotografije javnih osoba s tekstom i sloganom

Oglasi u obliku intervjua sa stranačkim predstavnicima

Samo slogan stranke

Oglas u obliku proglasa

Poziv na stranačka događanja (skupove, koncerte i slično)

Fotografije "običnih građana" sa sloganima

Gospodarska i ostala infrastruktura sa sloganima i tekstom

Prirodni okoliš sa sloganima i tekstom

Samo slogani i tekst

Ukupno

\begin{tabular}{lllll} 
& & & \multicolumn{2}{l}{ Ukupno } \\
\cline { 3 - 4 } Cijela str. & $1 / 2$ str. & $1 / 4$ str. & $<1 / 4$ str. & $\mathrm{N} \%$
\end{tabular}

SDP

Fotografije stranačkih osoba sa sloganima

Fotografije stranačkih osoba sa sloganima i tekstom

Fotografije stranačkih osoba s tekstom

Samo fotografije stranačkih osoba

Fotografije javnih osoba s tekstom i sloganom

Oglasi u obliku intervjua sa stranačkim predstavnicima

Samo slogan stranke

Oglas u obliku proglasa

Poziv na stranačka događanja (skupove, koncerte i slično)

Fotografije "običnih građana" sa sloganima

Gospodarska i ostala infrastruktura sa sloganima i tekstom

Prirodni okoliš sa sloganima i tekstom

Samo slogani i tekst

Ukupno

Cijela

\section{HSS-HSLS}

Fotografije stranačkih osoba sa sloganima

Fotografije stranačkih osoba sa sloganima i tekstom

Fotografije stranačkih osoba s tekstom

Samo fotografije stranačkih osoba

Fotografije javnih osoba s tekstom i sloganom

Oglasi u obliku intervjua sa stranačkim predstavnicima

Samo slogan stranke

Oglas u obliku proglasa

$\begin{array}{rrrrrr}0,0 & 0,0 & 0,0 & 0,0 & 0 & 0,0 \\ 13,3 & 0,0 & 0,0 & 0,0 & 17 & 6,2 \\ 8,6 & 6,1 & 0,0 & 0,0 & 13 & 4,7 \\ 0,0 & 0,0 & 0,0 & 0,0 & 0 & 0,0 \\ 25,8 & 0,0 & 0,0 & 0,0 & 33 & 12,0 \\ 0,0 & 0,0 & 0,0 & 0,0 & 0 & 0,0 \\ 23,4 & 0,0 & 1,0 & 21,4 & 34 & 12,4 \\ 0,0 & 0,0 & 0,0 & 0,0 & 0 & 0,0 \\ 0,8 & 12,1 & 3,0 & 14,3 & 10 & 3,6 \\ 28,1 & 81,8 & 68,0 & 64,3 & 140 & 50,9 \\ 0,0 & 0,0 & 28,0 & 0,0 & 28 & 10,2 \\ 0,0 & 0,0 & 0,0 & 0,0 & 0 & 0,0 \\ 0,0 & 0,0 & 0,0 & 0,0 & 0 & 0,0 \\ 100,0 & 100,0 & 100,0 & 100,0 & 275 & 100,0\end{array}$

\begin{tabular}{rrrrrr}
0,0 & 0,0 & 0,0 & 0,0 & 0 & 0,0 \\
85,7 & 0,0 & 0,0 & 0,0 & 6 & 12,2 \\
0,0 & 0,0 & 0,0 & 0,0 & 0 & 0,0 \\
0,0 & 0,0 & 0,0 & 0,0 & 0 & 0,0 \\
0,0 & 0,0 & 0,0 & 0,0 & 0 & 0,0 \\
0,0 & 0,0 & 0,0 & 0,0 & 0 & 0,0 \\
0,0 & 0,0 & 50,0 & 71,8 & 29 & 59,2 \\
0,0 & 0,0 & 0,0 & 0,0 & 0 & 0,0 \\
14,3 & 100,0 & 50,0 & 28,2 & 14 & 28,6 \\
0,0 & 0,0 & 0,0 & 0,0 & 0 & 0,0 \\
0,0 & 0,0 & 0,0 & 0,0 & 0 & 0,0 \\
0,0 & 0,0 & 0,0 & 0,0 & 0 & 0,0 \\
0,0 & 0,0 & 0,0 & 0,0 & 0 & 0,0 \\
100,0 & 100,0 & 100,0 & 100,0 & 49 & 100,0 \\
& & & & & \\
13,3 & 66,7 & 73,3 & 3,9 & 27,0 & 36,5 \\
60,0 & 33,3 & 26,7 & 0,0 & 18,0 & 24,3 \\
0,0 & 0,0 & 0,0 & 0,0 & 0,0 & 0,0 \\
0,0 & 0,0 & 0,0 & 0,0 & 0,0 & 0,0 \\
0,0 & 0,0 & 0,0 & 0,0 & 0,0 & 0,0 \\
20,0 & 0,0 & 0,0 & 0,0 & 3,0 & 4,1 \\
6,7 & 0,0 & 0,0 & 46,2 & 13,0 & 17,6 \\
0,0 & 0,0 & 0,0 & 0,0 & 0,0 & 0,0 \\
\hline
\end{tabular}

(nastavak na sljedećoj stranici) 


\begin{tabular}{|c|c|c|c|c|c|c|}
\hline & & & & & & \\
\hline & & & & & Uku & pno \\
\hline Forma oglasa & Cijela str. & $1 / 2$ str. & $1 / 4$ str. & $<1 / 4$ str. & $\mathrm{N}$ & $\%$ \\
\hline Poziv na stranačka događanja (skupove, koncerte i slično) & 0,0 & 0,0 & 0,0 & 50,0 & 13,0 & 17,6 \\
\hline Fotografije "običnih građana" sa sloganima & 0,0 & 0,0 & 0,0 & 0,0 & 0,0 & 0,0 \\
\hline Gospodarska i ostala infrastruktura sa sloganima i tekstom & 0,0 & 0,0 & 0,0 & 0,0 & 0,0 & 0,0 \\
\hline Prirodni okoliš sa sloganima i tekstom & 0,0 & 0,0 & 0,0 & 0,0 & 0,0 & 0,0 \\
\hline Samo slogani i tekst & 0,0 & 0,0 & 0,0 & 0,0 & 0,0 & 0,0 \\
\hline Ukupno & 100 & 100 & 100 & 100 & 74 & 100 \\
\hline Ostali & & & & & & \\
\hline Fotografije stranačkih osoba sa sloganima & 12,5 & 30,0 & 83,33 & 11,1 & 11,0 & 26,2 \\
\hline Fotografije stranačkih osoba sa sloganima i tekstom & 0,0 & 20,0 & 0,0 & 0,0 & 2,0 & 4,8 \\
\hline Fotografije stranačkih osoba s tekstom & 0,0 & 0,0 & 0,0 & 5,6 & 1,0 & 2,4 \\
\hline Samo fotografije stranačkih osoba & 0,0 & 0,0 & 0,0 & 0,0 & 0,0 & 0,0 \\
\hline Fotografije javnih osoba s tekstom i sloganom & 0,0 & 20,0 & 0,0 & 0,0 & 2,0 & 4,8 \\
\hline Oglasi u obliku intervjua sa stranačkim predstavnicima & 0,0 & 0,0 & 0,0 & 0,0 & 0,0 & 0,0 \\
\hline Samo slogan stranke & 0,0 & 0,0 & 16,7 & 72,2 & 14,0 & 33,3 \\
\hline Oglas u obliku proglasa & 87,5 & 10,0 & 0,0 & 0,0 & 8,0 & 19,1 \\
\hline Poziv na stranačka događanja (skupove, koncerte i slično) & 0,0 & 0,0 & 0,0 & 0,0 & 0,0 & 0,0 \\
\hline Fotografije "običnih građana" sa sloganima & 0,0 & 10,0 & 0,0 & 0,0 & 1,0 & 2,4 \\
\hline Gospodarska i ostala infrastruktura sa sloganima i tekstom & 0,0 & 0,0 & 0,0 & 0,0 & 0,0 & 0,0 \\
\hline Prirodni okoliš sa sloganima i tekstom & 0,0 & 10,0 & 0,0 & 0,0 & 1,0 & 2,4 \\
\hline Samo slogani i tekst & 0,0 & 0,0 & 0,0 & 11,1 & 2,0 & 4,8 \\
\hline Ukupno & 100 & 100 & 100 & 100 & 42 & 100 \\
\hline
\end{tabular}

Polovina HDZ-ovih oglasa može se svrstati u oblik "fotografije običnih građana sa sloganima". SDP i koalicija HSS-HSLS nisu objavile ni jedan, dok su ostale stranke objavile tek jedan takav oglas. SDP je većinom (u 59\% slučajeva) objavljivao logotip i slogan, bez ikakva dodatnoga slikovnog materijala ili teksta (što je dobrim dijelom posljedica manjka prostora, naime već je spomenuto da je većinom biran najmanji format oglasa). HDZ je objavio i 33 (12\%) oglasa u kojima su građane na glasovanje za njegove kandidate pozivale javnosti poznate osobe. ${ }^{8}$ Koalicija HSS-HSLS i ostale stranke u većini su slučajeva rabile dvije vrste oglasa - "fotografije stranačkih osoba sa sloganom" (koalicija 36\%, ostale stranke $26 \%$ ) te "fotografije stranačkih osoba sa sloganom i tekstom" (koalicija $24 \%$, ostale stranke 5\%).

Ovdje valja napomenuti da prikazivanje javnosti poznatih osoba i prikazivanje "običnih" građana ima različite ciljeve. U oba slučaja oglas prikazuje pojedince, ali u slučaju javnosti poznatih osoba naglasak je na njihovim individualnim profesionalnim i privatnim kvalitetama, dok je u slučaju prikazivanja "običnih" građana naglasak na društvenim grupama kojima ti pojedinci pripadaju. Dosljedno tome, i ciljevi su objavljivanja tih vrsta oglasa različiti. Oglasima koji prikazuju javnosti poznate osobe želi se stvoriti dojam da one, kao svojevrsni autoriteti, podržavaju politiku stranke i jamče njezinu kvalitetu. Ako je pak riječ o čelnicima stranaka, tom se vrstom "personalizacije", između ostalog, stranku pokušava učiniti pre- 
DRUŠ. ISTRAŽ. ZAGREB GOD. 20 (2011) BR. 2 (1 112$)$

STR. 359-378

BALABANIĆ, I., MUSTAPIĆ, M., RIHTAR, S. "AMERIKANIZACIJA"... poznatljivijom i bliskom. Konačno, oglasima koji prikazuju "obične" građane naglašava se politička osjetljivost za poteškoće koje ih svakodnevno opterećuju, kao i namjera njihova rješavanja.

Dvije su najjače hrvatske stranke otprilike $10 \%$ oglasa posvetile isticanju vlastitih predsjednika, Ive Sanadera i Zorana Milanovića (HDZ 28 puta, SDP 5). U gotovo pola HDZ-ovih oglasa te vrste (13) Ivo Sanader prikazan je u društvu stranih političara i državnika, pa se može reći da je stranka koja je u vrijeme izborne kampanje bila na vlasti iskorištavala tu okolnost za isticanje simbola moći i statusa (ipak, uzme li se u obzir ukupan broj objavljenih oglasa, razmjerno skromno). ${ }^{9}$

Osim klasifikacije prema vrstama, provjereno je koji se sadržaj svakim oglasom naglašava, odnosno ističe li se u njemu posebno slogan, tekst (programske smjernice) ili slikovni materijal. Već je spomenuto da je glavnina SDP-ovih oglasa sadržavala jedino slogan, a oglasi koalicije HSS-HSLS u 51\% slučajeva fotografiju stranačkih osoba sa sloganom i/ili tekstom. HDZ-ovi oglasi u većini su slučajeva $(54 \%)$ bili svojevrsna kombinacija tekstualnoga i slikovnoga materijala popraćenoga sloganom. Uz slikovni materijal i slogan, kratko su navođene glavne programske smjernice, dotadašnji rezultati i dostignuća te obećanja koja će stranka ispuniti ako dođe na vlast.

U oglasima ostalih političkih stranaka najčešće je naglašavan slikovni materijal sa sloganom ili samo slogan (u $26 \%$, odnosno $33 \%$, slučajeva).

Interpretiraju li se navedeni nalazi oslanjajući se na, uvodno opisanu, Slavujevićevu (2005.) tipologiju slogana, gotovo pola $(48,9 \%)$ SDP-ovih oglasa sa sloganima može se uvrstiti u kategoriju slogana-poziva. HDZ-ovi slogani u većini su slučajeva $(59,1 \%)$ bili kombinacija slogana, teme i slogana poziva. Drugim riječima, stranka je sloganom naglašavala potrebu rješavanja određenoga problema, pozivajući ujedno da se upravo zbog toga za nju glasa. Oglase koji su sadržavali slogan-te$\mathrm{mu} u$ velikoj su mjeri rabile i ostale stranke (u 78\% slučajeva, čemu su najviše pridonijeli oglasi HSS-a i HSLS-a). ${ }^{10}$

Manja zastupljenost imidž-slogana u odnosu na ostale vrste ne mora nužno značiti i "niži" stupanj "amerikanizacije". Česta upotreba slogana kao jedinog (tekstualnog) sadržaja oglasa (posebno u slučaju SDP-a) već sama po sebi govori o komunikaciji koja je svedena na minimum složenosti, pa već i samim time odgovara "amerikaniziranom" stilu.

Osim formalnih obilježja ili razvrstavanja prema tipologiji slogana, provjerena je i tematska usmjerenost oglasa. Rezultati su pokazali da se u gotovo svim HDZ-ovim oglasima $(95,3 \%)$ ona može prepoznati, dok se među oglasima SDP-a ona zapaža u tek u nešto više od trećine slučajeva (36,7\%). Poput SDP-a, i koalicija i ostale stranke rabile su tematski usmjerene oglase znatno manje od HDZ-a, iako nešto manje skrom- 
DRUŠ. ISTRAŽ. ZAGREB GOD. 20 (2011), BR. $2(112)$

STR. $359-378$

BALABANIĆ, I., MUSTAPIĆ M., RIHTAR, S.: "AMERIKANIZACIJA"... no (45\% koalicija i $40 \%$ ostale stranke). Uz veliku zastupljenost ove vrste oglasa, HDZ je u njima pokrio i najširi raspon tema.

Ako se iz ukupnoga tematskog raspona izdvoji ciljano obraćanje pojedinim segmentima biračkoga tijela, bez obzira na to je li riječ o cijelom ili tek dijelu sadržaja oglasa, može se uočiti da je u tom načinu predstavljanja prednjačio HDZ. Ta se stranka isključivo dijaspori, poljoprivrednicima, umirovljenicima, braniteljima ili mladima izravno obratila cijelim sadržajem oglasa u $41 \%$ slučajeva, dok je u dodatnih $32 \%$ oglasa nekoj od spomenutih skupina posvećen barem dio teksta. SDP nije upotrijebio ni jedan oglas čiji bi sadržaj u cjelini bio posvećen nekoj od skupina birača, a tek su dva oglasa djelomice namijenjena umirovljenicima. Koalicija HSS-HSLS posvetila je $26 \%$ svojih oglasa u cjelini mladima, umirovljenicima, dijaspori, stanovnicima pojedinih (zanemarenih) regija ili poljoprivrednicima. U još dva oglasa koalicija se, uz ostali sadržaj, obratila radnicima i seljacima. Ostale stranke jedan su cijeli oglas namijenile manjinama, dok je u $14 \%$ slučajeva tematika namijenjena umirovljenicima, mladima, poljoprivrednicima ili stanovnicima pojedinih regija bila uklopljena $u$ širi raspon sadržaja.

Kad je riječ o svrsi, personalizacija se može prepoznati u desetak posto oglasa HDZ-a i SDP-a. Pritom valja spomenuti da HDZ, osim objavljivanja fotografija vlastita predsjednika, ni jedan oglas nije posvetio liku nekog od ostalih članova stranke, dok je SDP u tu svrhu utrošio samo jedan (na Ljubu Jurčića). Za razliku od toga, fotografije nekog od članova stranaka prikazane su u $51 \%$ oglasa koalicije HSS-HSLS. Budući da su to u najvećem broju slučajeva bile fotografije Stipe Gabrića Jambe (HSS) i Stanka Zrilića (HSLS) u Slobodnoj Dalmaciji, u kojoj je objavljen najveći broj i dominantan udio oglasa najvećega formata, jasno je da se $\mathrm{u}$ ovom slučaju radilo o ciljanu predstavljanju za područje Dalmacije, zasnovanom na lokalnoj popularnosti spomenutih političara. Nalaz prema kojem su i ostale stranke objavile više oglasa s fotografijama članova, a ne predsjednika (33\% prema $7 \%$ ), navodi na zaključak da su i one računale s lokalnom popularnosti nekog od njih.

Znatno zastupljenije od personalizacije u oglasima HDZ-a bilo je nuđenje rješenja pojedinih problema ili davanje konkretnih obećanja (u gotovo pola oglasa, $48,2 \%$ ). SDP je pak u relativno najvećoj proporciji svojih oglasa $(36,7 \%)$ objavio samo kratke parole (primjerice, 'Pošteno!', 'Zaokruži' i slično).

Na kraju, negativnoj su kampanji, odnosno "ocrnjivanju" političkih protivnika, obje vodeće stranke posvetile podjednak broj, desetak posto zakupljenoga oglasnog prostora (HDZ 10,9\%, SDP $10,2 \%$ ). Za tom taktikom nije posegnula ni jedna od ostalih stranaka. 
Istraživanjem se namjeravalo utvrditi da li i u kojoj mjeri, na primjeru parlamentarnih izbora 2007. godine, stranačko oglašavanje u hrvatskom tisku odražava globalni trend "amerikanizacije" predizborne političke komunikacije. Uvodno je navedeno da pojam "amerikanizacija", na konkretnoj ili operativnoj razini, obuhvaća personalizaciju stranaka u javnosti isticanjem osoba i uloga njihovih predsjednika (predsjednica), članova ili $u$ javnosti popularnih osoba (najčešće estradnih i sportskih zvijezda), segmentaciju biračkoga tijela u marketinške svrhe (uz izravno i specifično sročeno obraćanje svakom segmentu zasebno), naglašavanje slikovnoga materijala oglasa, uz minimum teksta (uglavnom u obliku slogana), iskorištavanje vladajuće pozicije za isticanje simbola moći i statusa te oglasa izravno usmjerenih protiv drugih stranaka (negativna kampanja).

Predočeni rezultati, sagledani u cjelini, potvrđuju prisutnost opisanih trendova, jer su $u$ analiziranim oglasima, $u$ većoj ili manjoj mjeri, uočeni svi nabrojeni elementi: personalizacija isticanjem predsjednika glavnih stranaka, Ive Sanadera i Zorana Milanovića (kao i stranačkih osoba u oglasima ostalih stranaka); prisutnost estradnih i sportskih zvijezda u političkoj kampanji (primjerice, HDZ-ovi oglasi s nogometašem Nikom Kovačem); iskorištavanje vladajuće pozicije za isticanje simbola moći i statusa (oglasi u kojima je predsjednik HDZ-a u društvu stranih državnika); objavljivanje oglasa izravno usmjerenih protiv političkih protivnika (negativna kampanja); segmentacija biračkoga tijela (posebice HDZ-ovi oglasi); naglašavanje slogana, bez iznošenja programskih smjernica (primjerice, oko 60\% svih SDP-ovih oglasa).

Usporedba među strankama pokazuje da se, po opsegu i stilu oglašavanja u tisku, dvije najveće među njima ujedno najviše i razlikuju.

HDZ je znatno više od ostalih uložio u novinsko oglašavanje, što mu je, već samo po sebi, osiguralo i više prostora za upotrebu pojedinih elemenata "amerikanizacije" kampanje (sličan nalaz navodi i Lalić, komentirajući oglašavanje na televiziji prije izbora 2003.; Lalić, 2004.). Veliki formati oglasa omogućili su da njih više od $70 \%$ sadrži slikovni prilog (bez obzira na to jesu li objavljene fotografije predsjednika stranke, javnosti poznatih osoba ili "običnih" građana). Uz to, u svim je oglasima upotrijebljen najmanje jedan element, a često i više tipičnih elemenata "amerikaniziranog" načina komunikacije. Ukupno uzevši, može se reći da su upotrijebljeni zapravo svi. SDP je u tom pogledu bio mnogo skromniji. Većinom preferirani, minimalni format oglasa nije, sam po sebi, omogućio intenzivniju upotrebu slikovnoga materijala, a ni količina teksta nije mogla biti velika. Stoga su plasirane kratke i općenite 
DRUŠ. ISTRAŽ. ZAGREB GOD. 20 (2011), BR. 2 (112)

STR. $359-378$ M., RIHTAR, S.

"AMERIKANIZACIJA"..
BALABANIĆ, I., MUSTAPIĆ,

parole, fraze ili slogani, a ne razrađenije i ciljane poruke namijenjene specifičnim segmentima biračkoga tijela. Nisu angažirane javnosti poznate osobe (primjerice, s estrade ili iz sporta), a nije se ni posegnulo za isticanjem simbola moći i statusa.

Koalicija HSS-HSLS objavila je znatno više oglasa od SDP-a, no i znatno manje od HDZ-a, a i po upotrebi pojedinih elemenata "amerikanizacije" može se smjestiti nekamo između njih. Potonje vrijedi i za ostale stranke, ako se sagledaju zajedno. Najveća specifičnost koalicije pritom se očitovala u objavljivanju fotografija vlastitih članova, i to, kako je ranije spomenuto, zbog ciljanoga regionalnog predstavljanja.

Budući da za to nema objektivnoga referentnog okvira, na temelju ukupnoga broja oglasa (441) objavljenih tijekom kampanje ne može se zaključiti je li tisak kao promotivni medij optimalno iskorišten ili je eventualno podcijenjen. No 49 SDP-ovih u odnosu na 275 objavljenih oglasa HDZ-a (i 74 koalicije HSLS-HSS), uz razlike u preferiranim formatima, jasno pokazuje da je, u najmanju ruku, SDP tisak smatrao manje važnim za vlastito predstavljanje. To donekle iznenađuje zna li se da je tom mediju izložen proporcionalno veći broj njegovih potencijalnih birača (istraživački podaci pokazuju da su čitatelji informativno-političkog tiska u Hrvatskoj, u usporedbi s ostalim građanima, u prosjeku mlađi, obrazovaniji, višega životnog standarda, urbanijega rezidencijalnog statusa i podrijetla, intenzivnije medijski uključeni te da su skloniji izbornoj participaciji, a potom i glasanju za opcije koje zastupaju stranke poput SDP-a; Lamza Posavec i Rihtar, 2003.). Je li zanemarivanje tiska (valja se podsjetiti i toga da je SDP čak $60 \%$ oglasa objavio u samo jednim novinama, Novom listu) u ovom slučaju rezultat strateškog izbora (manjeg ulaganja u kampanju općenito ili intenzivnijeg oglašavanja u ostalim medijima ne bi li se pokušalo pridobiti manje sklonu publiku) ili je pak posljedica formalnih zapreka (primjerice, nedovoljnoga oglasnog prostora koji su već prije zakupili konkurenti) na ovom se mjestu ne može odgovoriti.

Za razliku od SDP-a, kojem je već i preferirani minimalni format oglasa onemogućio oslanjanje na širi repertoar elemenata "amerikanizirane" promocije (što ne znači da uopće nisu upotrijebljeni), ostale su ga stranke, iako inicijalno ograničenijih sredstava i logistike, rabile u većoj mjeri, za što je "najzaslužniji" HDZ, koji je i najviše uložio u novinsko predstavljanje.

\section{ZAKLJUČAK}

Sažet pregled upotrebe pojedinih elemenata "amerikanizacije" u cjelini pokazuje da su u $63 \%$ od ukupno objavljenih 440 oglasa $u$ analiziranom tisku objavljene fotografije predsjednika i članova stranaka, nestranačkih javnih ličnosti ili "običnih" ljudi. Kad je riječ o tekstualnom sadržaju, isključivo slogani 
DRUŠ. ISTRAŽ. ZAGREB BR. 2 (112),

STR. 359-378

BALABANIĆ, I., MUSTAPIĆ, M., RIHTAR, S. "AMERIKANIZACIJA". GOD. 20 (2011)

upotrijebljeni su u $61 \%$ slučajeva, dvostruko više u odnosu na $30 \%$ oglasa koji su sadržavali tekst barem nešto širega ili složenijega sadržaja. Stranke su se ciljano obratile pojedinim skupinama birača u $54 \%$, a za ocrnjivanjem protivnika posegnulo se u $8 \%$ slučajeva. Simboli moći i statusa isticani su najmanje, mogli su se primijetiti u $3 \%$ oglasa.

Analizirani rezultati pokazuju da se, iako su neki upotrijebljeni obilatije, a neki skromnije, iskoristilo zapravo sve elemente "amerikanizacije", pri čemu su ih vodeće stranke rabile proporcionalno raspoloživom oglasnom prostoru (HDZ najviše, SDP najmanje). Ta činjenica opravdava zaključak prema kojem je u nas, kad je u pitanju oglašavanje u tisku (poput onoga na televiziji; Lalić, 2004.), u dobroj mjeri usvojen "amerikanizirani" način predizbornoga političkog predstavljanja.

\section{BILJEŠKE}

${ }^{1}$ Debord je 1960-ih suvremeno društvo Zapada nazvao "društvom hiperspektakla".

2 Primjerice, Zakon o izmjenama i dopunama Zakona o izborima zastupnika u Hrvatski državni sabor, NN, 53, 2003.

${ }^{3}$ Kako kaže Lippmann, sve su novine, kada dođu do čitatelja "rezultat niza selekcija u pogledu toga koji će se članci tiskati, na koje će se mjesto staviti, koliko će svaki od njih zauzeti prostora i što će se u svakom od njih naglasiti" (Lippmann, 1954., 354).

${ }^{4}$ Kad je riječ o stilu političkog oglašavanja u Hrvatskoj, Lalić je (2004.) utvrdio prisutnost elemenata "amerikanizacije" u televizijskoj kampanji prije izbora 2003

5 Termin "javnosti poznate osobe" ovdje i u daljem tekstu ne uključuje političare, iako ulaze u tu kategoriju. Političari se u daljem tekstu, gdje je to potrebno, eksplicitno navode kao zasebna kategorija.

${ }^{6}$ Podudarnost je analizirana na uzorku od 50 oglasa. Služili smo se slučajnim sustavnim uzorkom, s time da je svaki analitičar analizirao 50 priloga koje je prethodno analizirao drugi analitičar.

7 Tako su na parlamentarnim izborima 2007. godine HDZ i SDP zajedno dobili 122 saborska mandata, dok su sve druge stranke osvojile 31 (uključujući i 8 zastupnika nacionalnih manjina).

8 Ovdje je, primjerice, riječ o oglasima s kapetanom hrvatske nogometne reprezentacije Nikom Kovačem, kojim se naglašava problematika prava dijaspore na glasanje za izbor zastupnika u Sabor Republike Hrvatske.

${ }_{9}^{9}$ Nalik tome, u kampanji za izbore 2003. godine, kad je HDZ nastupao u ulozi oporbene stranke, plasirani su oglasi na kojima je prikazivan Ivo Sanader u društvu tadašnjih predsjednika velikih europskih stranaka kako bi se na taj način barem djelomično nadoknadio manjak simbola moći i statusa što ga redovito imaju stranke koje obnašaju vlast prije izbora.

10 Ponajprije u vezi s centralizacijom države i ZERP-om. 
Biocca, F. (1991.), What is the Language of Political Advertising. U: F. Biocca (ur.), Television and Political Advertising. Volume 2. Signs, Codes and Images (str. 3-10), Hillsdale, Erlbaum Associates.

Blumler, J. G. i Kavanagh, D. (1999.), The Third Age of Political Communication: Influences and Features. Political Communication, 16 (3): 209-230. doi:10.1080/105846099198596

Castells, M. (2004.), The Information Age: Economy, Society and Culture vol. 2: The Power of Identity, Oxford: Blackwell Publishing Ltd.

Corner, J. (1995.), Television Form and Public Address, London: Edward Arnold.

Corner, J. i Pels, D. (2003.), Introduction: The Re-Styling of Politics. U: J. Corner i D. Pels (ur.), Media and the Restyling of Politics: Consumerism, Celebrity and Cynicism (str. 1-18), London, Sage Publications.

Crowley, D. (1998.), The Propaganda Poster. U: M. Timmers (ur.), The Power of the Poster (str. 100-145), London, V\&A Publications.

Debord, G. (1999.), Društvo spektakla - društva spektakla, Zagreb: Arkazin. Diamond, E. i Bates, S. (1992.), The Spot, Cambridge: MIT Press.

Doulkeri, T. i Kotzaivazoglou, I. (2007.), The Evolution in Newspaper Advertising of Parliamentary Candidates in Thessaloniki in the Period 1989-2000, http://www.psa.ac.uk/journals/pdf/5/2007/Doulkeri.pdf (20. 1. 2009.)

Franklin, B. (1994.), Packaging Politics: Political Communications in Britain's Media Democracy, London: Edward Arnold.

Greenway, J., Smith, S. i Street, J. (1992.), Deciding Factors in British Politics, London: Ruotledge.

Hardt, M. i Negri, A. (2003.), Imperij, Zagreb: Arkzin.

Holtz-Bacha, C. i Kaid, L. L. (1995.), Political Advertising in International Comparison. U: L. L. Kaid i C. Holz-Bacha (ur.), Political Advertising in Western Democracies (str. 3-14), London, Sage.

Holtz-Bacha, C. (2002.), Wahlkampf 2000. Entwicklungen und Trends in der US-amerikanischen Wahlkampf-PR. U: S. Becker-Sonnenschein i M. Schwarzmeier (ur.), Vom schlichten Sein zum schönen Schein? Kommunikationsanforderungen im Spannungsfeld von Public Relations und Politik (str. 179-194), Wiesbaden, Westdeutscher Verlag.

Holtz-Bacha, C. (2003.), Political Advertising during Election Campaigns. U: P. J. Maarek i G. Wolfsfeld (ur.), Political Communication in a New Era (str. 95-116), London, Routledge.

Joslyn, R. (1986.), Political Advertising and the Meaning of Elections. U: L. L. Kaid (ur.), New Perspectives on Political Advertising (str. 139-183), Carbondale, Southern Illinois University Press.

Kaid, L. L. (1995.), Political Advertising in the United States. U: L. L. Kaid i C. Holz-Bacha (ur.), Political Advertising in Western Democracies (str. 37-61), London, Sage.

Kaid, L. L. (2004.), Political Advertising. U: L. L. Kaid (ur.), Handbook of Political Communication Research (str. 155-202), New Jersey, Routledge. 
DRUŠ. ISTRAŽ. ZAGREB GOD. 20 (2011), BR. 2 (112),

STR. 359-378

BALABANIĆ, I., MUSTAPIĆ, M., RIHTAR, S.: "AMERIKANIZACIJA".
Kasapović, M. (2003.), Izborni leksikon, Zagreb: Politička kultura. Lalić, D. (2004.), Obilježja pakiranja politike u izbornoj kampanji HDZ-a i SDP-a 2003. godine. Politička misao, 41 (1): 55-73.

Lamza Posavec, V. i Rihtar, S. (2003.), Neke osobine publike informativno-političkog tiska. Društvena istraživanja, 12 (6): 927-956.

Lippmann, W. (1954.), Public Opinion, New York: Macmillan.

Mancini, P. i Swanson, D. L. (1996.), Politics, Media and Modern Democracy: Introduction. U: D. L. Swanson i P. Mancini (ur.), Politics, Media and Modern Democracy. An International Study of Innovations in Electoral Campaigning and Their Consequences (str. 1-28), Westport, Prager. Mayer, T. (2003.), Mediokracija - Medijska kolonizacija politike, Zagreb: Fakultet političkih znanosti.

McNair, B. (2003.), Uvod u političku komunikaciju, Zagreb: Fakultet političkih znanosti.

Newman, B. I. (1999.), Handbook of Political Marketing, Thousand Oaks: Sage.

Newman, B. I. i Perloff, R. M. (2004.), Political Marketing: Theory, Research, and Applications. U: L. L. Kaid (ur.), Handbook of Political Communication Research (str. 17-43), New Jersey, Routledge.

Qualter, T. (1991.), Advertising and Democracy in the Mass Age, Basingstoke: Macmillan.

Scammell, M. (1995.), Designer Politics: How Elections Are Won, London: Macmillan.

Scammell, M. (1999.), Political Marketing: Lessons for Political Science. Political Studies, 47 (4): 718-739. doi:10.1111/1467-9248.00228

Scammell, M. i Langer, A. (2006.), Political Advertising: Why is it so Boring? Media, Culture and Society, 28 (5): 763-784. doi:10.1177/016344 3706067025

Schiller, H. (1984.), Information and the Crisis Economy, Norwood: Ablex Publishing.

Slavujević, Z. (2005.), O sloganima političkih stranaka i kandidata. Sociološki pregled, 38 (1): 47-80.

Street, J. (2003.a), Masovni mediji, politika i demokracija, Zagreb: Fakultet političkih znanosti.

Street, J. (2003.b), Mediated Persona and Political Culture. U: J. Corner i D. Pels (ur.), Media and the Restyling of Politics: Consumerism, Celebrity and Cynicism (str. 85-98), London, Sage Publications.

Swanson, D. i Mancini, P. (1996.), Politics, Media and Modern Democracy, New York: Praeger.

Trent, J. S. i Friedenberg, R. V. (2007.), Political Campaign Communication. Principles and Practices, Lanham: Rowman \& Littlefield.

Van Zoonen, L. (2003.), After Dallas and Dynasty We Have Democracy: Articulating Soap, Politics and Gender. U: J. Corner i D. Pels (ur.), Media and the Restyling of Politics: Consumerism, Celebrity and Cynicism (str. 99-116), London, Sage Publications. 
DRUŠ. ISTRAŽ. ZAGREB GOD. 20 (2011), BR. 2 (112)

STR. $359-378$

BALABANIĆ, I., MUSTAPIĆ, M., RIHTAR, S.:

"AMERIKANIZACIJA".

\section{"Americanization" of}

\section{Pre-Election Campaign in Croatian} Daily Papers: 2007 Elections

Ivan BALABANIĆ, Marko MUSTAPIĆ, Stanko RIHTAR

Institute of Social Sciences Ivo Pilar, Zagreb

According to numerous literature, the main features of today's political communication are alienation of political parties, scientification, autonomous structure of communication and transformation of the citizens into the public. These features are in advertising, as a part of political communication in general, concretized as personalization by emphasizing leaders and other party members, by reduction of complex messages to slogans, by emphasizing symbols of power and status, as well as negative campaign. The described communication style is often labeled as "Americanized". In this article, by using the Croatian 2007 parliamentary elections as an example, the measure of "Americanization" of the campaign in daily newspapers is empirically verified by content analysis of the population of advertisements in six main papers during the official campaign. The results showed that HDZ (Hrvatska demokratska zajednica, Croatian Democratic Union), which invested in newspaper advertising more than other parties, adopted all elements of the "Americanized" campaign style. The finding that other parties, more or less, used the same communication elements as well, leads to the conclusion that "Americanized" style of political advertising in Croatian daily papers has been adopted to a considerable extent.

Keywords: pre-election campaign, political advertising, daily papers, "Americanization"

\section{"Amerikanisierung" des Wahlkampfs in der kroatischen Presse: Wahlen 2007}

Ivan BALABANIĆ, Marko MUSTAPIĆ, Stanko RIHTAR Ivo Pilar-Institut für Gesellschaftswissenschaften, Zagreb

In zahlreichen fachliterarischen Veröffentlichungen zur politischen Kommunikation wird angeführt, ihre Hauptmerkmale bestünden in der Entfremdung der Parteien von den Bürgern, ferner in der Verwissenschaftlichung und autonomen Struktur dieser Kommunikation sowie in der Transformierung der Bürger und Wähler zu einem bloßen Publikum. Im Hinblick auf die Werbekampagne als ein Teilgebiet der politischen Kommunikation offenbaren sich auf operativer Ebene, insbesondere im Wahlkampf, besagte 
DRUŠ. ISTRAŽ. ZAGREB GOD. 20 (2011)

BR. 2 (112)

STR. 359-378

BALABANIĆ, I., MUSTAPIĆ, M., RIHTAR, S.

"AMERIKANIZACIJA".
Parteichefs (und anderer Parteimitglieder), als Formulierung komplexer programmatischer Richtlinien in Form von Slogans, als Demonstration von Macht- und Statussymbolen sowie als direkte Angriffe gegen politische Konkurrenten (negativer Wahlkampf). Ein solcher Wahlkampfstil gilt mitunter als "amerikanisiert". In der vorliegenden Arbeit wird untersucht, ob im Vorfeld der kroatischen Parlamentswahlen 2007 Praktiken eines amerikanisierten Wahlkampfstils in den Printmedien zu erkennen waren. Eine entsprechende Analyse stützte sich auf politische Werbetexte, die während des offiziellen Wahlkampfs in sechs führenden Tageszeitungen erschienen, und ergab, dass Elemente einer "Amerikanisierung" in Werbetexten der HDZ (Kroatische Demokratische Gemeinschaft) am stärksten ausgeprägł waren. Im Übrigen hatte die HDZ auch mehr als alle anderen Parteien in Wahlkampftexte dieser Art investiert. Da aber auch die politischen Konkurrenten in größerem oder geringeren Maße auf diese Art Wahlkampf betrieben, kommen die Verfasser zu dem Schluss, dass eine "Amerikanisierung" des Wahlkampfs auch hierzulande zügig voranschreitet.

Schlüsselbegriffe: Wahlkampf, politische Werbung, Tagespresse, „Amerikanisierung” des Wahlkampfs 